\title{
Diagnostics, treatment, and follow-up in craniopharyngioma
}

\section{Hermann L. Müller *}

Department of Pediatrics, Klinikum Oldenburg, Oldenburg, Germany

\section{Edited by:}

Jörg Flitsch, University Hospital

Hamburg-Eppendorf, Germany

\section{Reviewed by:}

Fahrettin Kelestimur, Erciyes

University, Turkey

Vera Popovic-Brkic, University

Belgrade, Serbia

${ }^{*}$ Correspondence:

Hermann L. Müller, Department of Pediatrics, Zentrum für Kinder- und Jugendmedizin, Klinikum Oldenburg, Rahel-Straus-Strasse 10, 26133

Oldenburg, Germany.

e-mail:mueller.hermann@

klinikum-oldenburg.de
Craniopharyngiomas are partly cystic embryogenic malformations of the sellar and parasellar region, with up to half the $0.5-2.0$ new cases per million population per year occur in children and adolescents. Diagnosis profile for pediatric and adult craniopharyngioma is characterized by a combination of headache, visual impairment, and polyuria/polydipsia, which can also include significant weight gain. In children, growth retardation, and/or premature puberty often occur later or postoperatively. Recommended therapy with favorable tumor localization is complete resection; with unfavorable tumor localization (optic nerve and/or hypothalamic involvement), consensus is still pending whether a limited resection followed by local irradiation is more prudent. Even though overall survival rates are high (92\%), recurrences after complete resection and progressions after incomplete resection can be expected. Accordingly, a randomized multinational trial (KRANIOPHARYNGEOM 2007) has been established to identify optimal diagnosis, treatment (particularly the ideal time point of irradiation after incomplete resection), and quality of life strategies of this chronic disease - most notably the morbid hypothalamic obesity in 50\% of long-term survivors. We report on craniopharyngioma origins, its pathological manifestations, and specific challenges these sequelae pose regarding diagnosis, treatment, and life-long multi-discipline quality of life management for both adult and childhood craniopharyngioma patients.

Keywords: craniopharyngioma, obesity, hypothalamus, pituitary, quality of life, neurosurgery, irradiation, brain tumors

\section{INTRODUCTION}

Craniopharyngioma is a rare, non-glial, non-malignant intracranial tumor derived from a malformation of embryonal tissue. The pathogenesis of craniopharyngioma is currently debated between two primary hypotheses: one describes tumor origin as ectodermal remnants of Rathke's pouch; the second argues craniopharyngioma represents a malformation of residual embryonal epithelium of the anterior pituitary gland and anterior infundibulum (Garré and Cama, 2007; Müller, 2010). Anywhere from 30 to 50\% of the 0.5 to 2 cases per million persons per year manifest during childhood and adolescence (Bunin et al., 1998; Nielsen et al., 2011), representing $1.2-4 \%$ of all childhood intracranial tumors. In childhood and adolescence, histological type is usually adamantinomatous with cyst formation (Müller-Scholden et al., 2001; Rushing et al., 2007). Incidences of adult onset craniopharyngioma (usually between ages 50 and 75) most often present with a squamous-papillary histological type (Rushing et al., 2007). More than $70 \%$ of craniopharyngioma of the adamantinomatous type bear a mutation of the $\beta$-catenin gene, which is not detectable in the papillary type of craniopharyngioma (Hölsken et al., 2010).

The German Childhood Cancer Registry obtained data on 496 patients in whom a craniopharyngioma was diagnosed at age $\leq 18$ years from 1980 to 2007 . Of these, 451 patients (91\%) were younger than 15 years-of-age at the time of diagnosis. The sex ratio was $1: 1$ and the median age at primary diagnosis was 8.6 years; survival rate (1980-2007) was $97 \%$ at 3 years, $96 \%$ at 5 years, and
93\% at 10 years after diagnosis. Patients who were diagnosed and treated in the 1980s had a lower survival rate than those diagnosed in the 1990s. For example, the survival rate at 5 years was $91 \%$ for patients diagnosed in the 1980 s versus $98 \%$ for those diagnosed in the 1990s (Müller et al., 2003c). This observation is supported by other reports (Sherlock et al., 2010), indicating that mortality is increased in childhood craniopharyngioma patients compared to general population.

\section{DIAGNOSIS - CLINICAL MANIFESTATIONS AND IMAGING METHODS}

A background study of craniopharyngioma patients reveals initial symptoms often occur long before diagnosis is made (Müller, 2010, 2011), the non-specific manifestations of increased intracranial pressure such as headache and nausea often going unrecognized as primary symptoms of craniopharyngioma. Other manifestations of the craniopharyngioma diagnostic profile can include visual impairment (62-84\%) and endocrine deficits (52$87 \%$; Figure 1). Craniopharyngioma tumors that involve the hypothalamic-pituitary axis can affect the secretion of growth hormone $(75 \%)$, gonadotropins (40\%), adrenocorticotropic hormone (ACTH; 25\%), and thyroid-stimulating hormone (TSH; $25 \%)$. Growth impediment caused by these hormonal disturbances often appears as early as 12 months of age; however, premature puberty and/or unmanageable weight gain are more often the precipitating factors preceding clinical diagnosis in older children 


\section{$\%$}

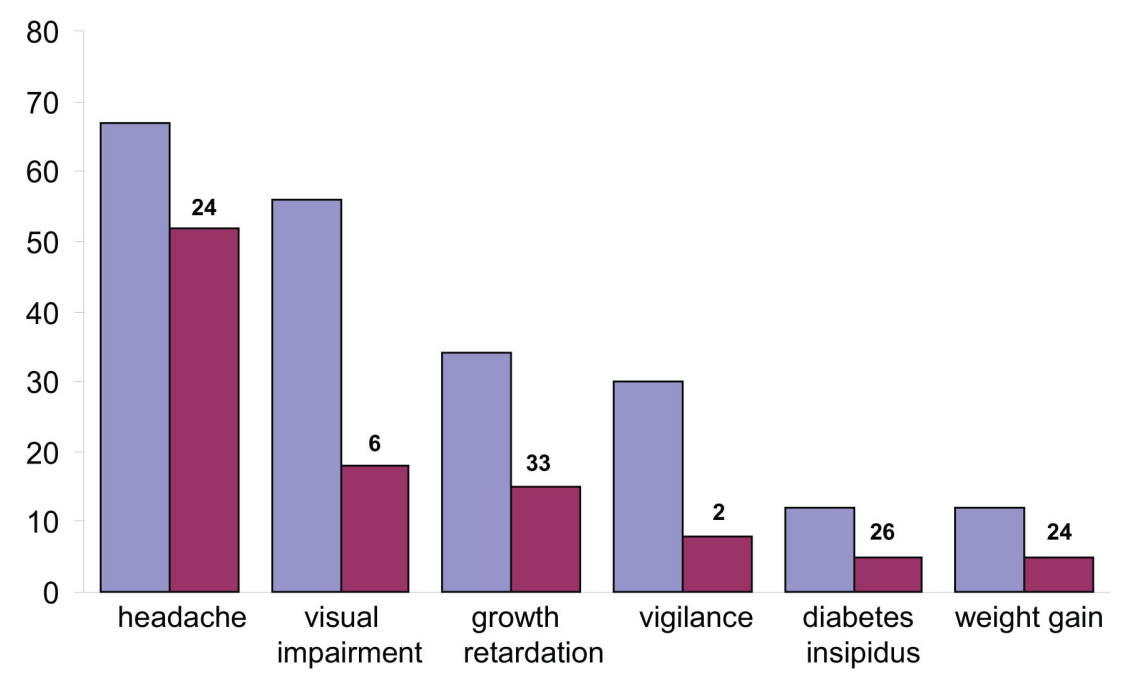

FIGURE 1 | Manifestations before diagnosis of craniopharyngioma in children and adolescents. Frequency of occurrence of each manifestation before diagnosis (blue) and frequency of occurrence as the initial manifestation (red). The median time (month) from the appearance of each initial manifestation until diagnosis is indicated above each red column. In the overall group, the median time from the initial manifestation of disease until diagnosis was 12 months, with a range of 0.01-96 months. (Modified from Müller et al., 2003c, with the kind permission of Springer).
(Müller, 2010). In summary, young children presenting symptoms of decreased growth rate, older children presenting symptoms of premature puberty and/or unmanageable weight gain, patients (adults or children) presenting headache, visual impairment, and/or unmanageable weight gain, and/or polydipsia/polyuria should arouse suspicion of craniopharyngioma (Müller, 2010).

The combination of solid, cystic, and calcified tumor components is an important radiological clue to craniopharyngioma diagnosis (Warmuth-Metz et al., 2004). The signal intensity of craniopharyngioma in magnetic resonance imaging (MRI) is highly variable, as it depends on the protein content of the cysts. Solid tumor portions and cyst membranes appear isointense in T1-weighted images, often with a mildly heterogeneous structure (Figure 2). MRI before and after gadolinium application is the standard imaging for detection of craniopharyngioma, but because CT is the only way to detect or exclude calcification, which is found in approximately $90 \%$ of tumors, (Warmuth-Metz et al., 2004), a sellar or parasellar mass detected on MRI should be further imaged by native CT for detection of calcifications.

\section{TREATMENT - CHALLENGES AND STRATEGIES}

Disturbance of cerebrospinal fluid (CSF) flow often causes hydrocephalus, which, depending on severity, must be stabilized by surgical treatment. Tumor resection is the first-choice treatment for restoring normal CSF flow, but a pre-surgery shunt operation may also be required. For a craniopharyngioma with large cystic components, stereotactic, or open implantation of an intracystic catheter is a proven treatment both for the relief of pressure and, in some cases, for the instillation of sclerosing substances (bleomycin). An intracystic catheter with a subcutaneous reservoir can be effective for reducing cyst volume and is particularly appropriate for infants and toddlers where extending the interval until radiotherapy or surgical resection is advantageous in some cases. For patients experiencing preoperative visual impairment due to large cysts exerting pressure on the optic nerve, a two-staged treatment approach is proposed, with cyst drainage to relieve pressure and improve vision, followed by resection (Choux et al., 1991).

After preoperative assessment of calcifications by CT, the recommended therapy for favorably tumor localized tumors is complete resection while preserving visual, hypothalamic, and pituitary functions (Choux et al., 1991; Müller, 2006). However, radical resection, especially in infants and small children, is problematic due the heightened risk of surgically induced deficits (mainly hypothalamic) and the susceptibility of children to recurrence (23\%), even in apparently complete resections. For topographicalanatomical reasons, transsphenoidal surgery is the proven neurosurgical technique for minimizing disturbance to these structures (Fahlbusch et al., 1999). Following postoperative MRI confirmation of complete resection, a post-surgical native CT of the sellar/parasellar area is recommended for reconfirmation of complete resection. A right frontotemporal operative approach is standard, although localization of craniopharyngioma should dictate the approach. Intrasellar craniopharyngioma can be approached via transsphenoidal route. However, childhood craniopharyngioma usually extends to the suprasellar area and must be removed through a transcranial approach. For topographical-anatomical reasons, transsphenoidal surgery has proven advantageous for minimizing disturbance to hypothalamic functions (Fahlbusch et al., 1999).

For unfavorably localized tumors (optic nerve and/or hypothalamic involvement), a limited resection followed by local irradiation is statistically favorable: the risk of progression is $71-90 \%$ without postoperative radiotherapy (Figure 3), but drops to $21 \%$ if combined with postoperative radiotherapy (Becker et al., 1999; 


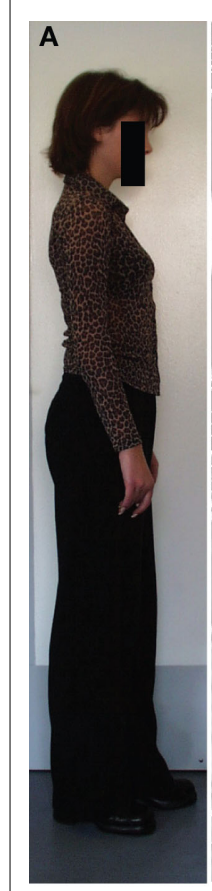

$20 \mathrm{y}$.

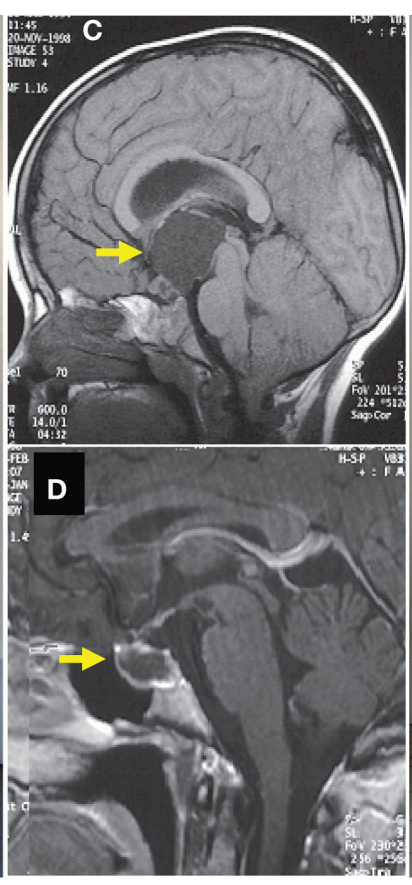

$32 \mathrm{y}$.

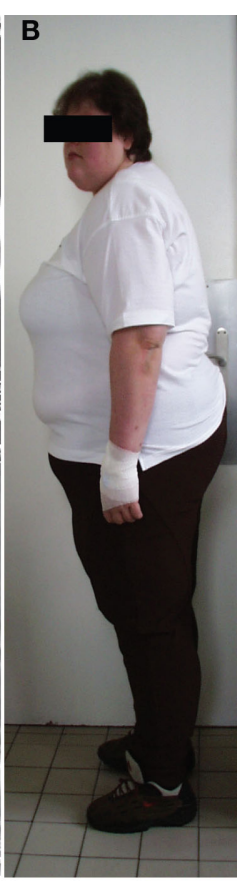

FIGURE 2 | Degree of obesity in relation to the localization of childhood craniopharyngioma. In both patients craniopharyngioma (as indicated by arrow on MRI before surgery) could be completely resected. Both patients had complete hypopituitarism after surgery requiring endocrine substitution of all hypothalamic-pituitary axes. The patient depicted in (B) developed severe obesity due to hypothalamic lesions of suprasellar parts of craniopharyngioma (C). The patient depicted in (A) presented with a small tumor confined to the sellar region (D). After complete resection she kept normal weight without any eating disorders. (Modified from Müller et al., 2003c, with the kind permission of Springer).

Einhaus and Sanford, 2007). Nevertheless, neurosurgical strategies to treat craniopharyngioma are a matter of debate in the literature (Fischer et al., 1990; Yasargil et al., 1990; Hetelekidis et al., 1993; Rajan et al., 1993; Merchant et al., 2002b; DiRocco et al., 2006; Puget et al., 2006).

The difficulty in striking the correct decision regarding treatment is reflected in two recent reports that reflect some telling trends: the first is Necker Hospital (Puget et al., 2007), which historically is more surgically oriented; and the second is in North America (Merchant et al., 2006), which historically has practiced a more conservative approach. The North American report states that current cases are now treated with moderate to aggressive surgery where $42 \%$ of patients undergo limited surgery before irradiation. Puget et al., authors of the Necker report state that $96 \%$ of recent cases are surgically treated $(23 \%$ achieving complete resection, $73 \%$ subtotal resection), and that combined treatment (surgical plus radiotherapy) is performed in half the cases following subtotal resection. The trend seems to be toward combined treatment (surgery plus post-surgical radiotherapy) in centers with historically prevalent surgical approaches, and toward more radical surgical treatment strategies in centers historically conservative-oriented.
In addition to difficulties in deciding the degree of resection, the timing of postoperative residual tumor irradiation remains unclear and controversial (Regine and Kramer, 1992; Stripp et al., 2004; Moon et al., 2005; Tomita and Bowman, 2005; Merchant et al., 2006; Müller et al., 2006b). Some favor immediate irradiation following surgical procedure and some purport a waitand-see approach to minimize both the necessity for irradiation and sequelae associated with radiation therapy. Proactive postsurgical irradiation to prevent tumor progression is favored by the above-mentioned North American Center (Merchant et al., 2006). But even though immediate postoperative irradiation significantly delays tumor progression, progression-contingent irradiation is effective, reflected in its unaffected overall survival rates. These contrasting approaches have been retrospectively compared by three series (Stripp et al., 2004; Moon et al., 2005; Tomita and Bowman, 2005). Moon et al., reported no overall survival rate differences between the two strategies. Tomita et al., reported that for those patients undergoing immediate postoperative irradiation after complete resection, $83 \%$ were relapsefree after 5 years and $70 \%$ were relapse-free after 10 years. For those undergoing incomplete resection followed by immediate irradiation, $71 \%$ were relapse-free after 5 years and 36\% were relapse-free after 10 years. Only $9 \%$ were relapse-free after 5 years when incomplete resection was not immediately combined with radiation therapy. Progression-contingent irradiation achieved similar survival- and progression-free survival rates of 90 and $70 \%$, respectively, meaning progression-contingent irradiation in this series also was highly effective. However, the interpretation of these studies is confounding by different indications for treatment. They also only reflect relapse-free survival rates and do not include consequences of craniopharyngioma QoL sequelae.

The target volume of irradiation is calculated based on CT and/or MRI images. Current imaging techniques with enhanced resolutions allow a safety margin ideally no greater than $5 \mathrm{~mm}$, depending on the tumor location, size, composition (solid, cystic, calcified), and adjacent structure involvements (hypothalamicpituitary axis and/or optic nerve or chiasm), requiring a larger safety margin if the hypothalamus is involved. Three-dimensional planning and multi-field techniques with individual field configurations (collimation) are recommended to protect radiosensitive structures and to provide a maximal dose fall-off between the tumor and the adjacent structures (Becker et al., 1999; Einhaus and Sanford, 2007).

Due to the low histological malignancy of craniopharyngiomas and especially because they are located near essential structures regulating eyesight, growth, and energy homeostasis, proton beam therapy appears to be a promising therapeutic option, offering a more protective radio-oncological technique than conventional external irradiation (Baumert et al., 2004; Fitzek et al., 2006; Luu et al., 2006). Also reported as a promising treatment technique is the intracystic instillation of interferon alpha (Ierardi et al., 2007). The stereotactic instillation of radioisotopes is mainly applicable to monocystic recurrences of craniopharyngioma, which is recommended for pre-surgical treatment of large cystic tumors and for tumors that recur after both surgery and percutaneous radiation therapy. 


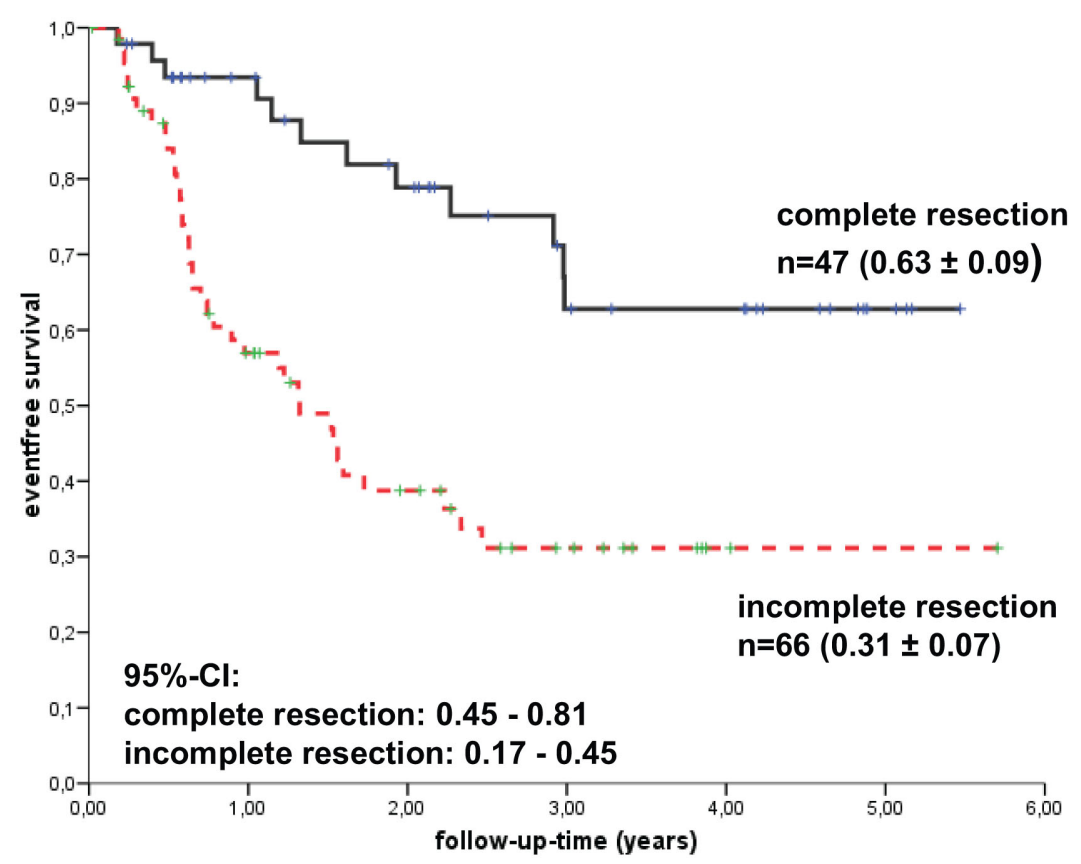

FIGURE 3 | Kaplan-Meier analyses of event-free survival rates (EFS) depending on the extent of resection among the 117 craniopharyngioma patients recruited in the trial KRANIOPHARYNGEOM 2000. (Modified from Müller et al., 2010, with the kind permission of Karger).
Other therapeutic options, including stereotactic gammaradiotherapy (Gamma Knife), are less promising due to limited experience; and in the case of single-dose convergence irradiation, of little treatment value due to reasons related to radiation biology.

Beyond treatment success ratings of craniopharyngioma related to diagnostic and treatment strategies is the experience level of the neurosurgeon. A few studies have analyzed treatment outcome related to the neurosurgeons' experience (Sanford, 1994; Boop, 2007; Müller et al., 2011b). Both Sanford and Boop report a marked difference in outcome according to the neurosurgeons' experience with the condition. The most recent of the three reports (Müller et al., 2011b) analyzed craniopharyngioma outcome and prognosis relative to patient load of the treating neurosurgical centers, finding centers with lower craniopharyngioma patient load - and therefore relatively less experience treating craniopharyngioma - tended to use more radical surgical approaches, resulting in less favorable outcomes regarding obesity and other QoL considerations. Current literature advises a multidisciplinary team approach to craniopharyngioma treatment, enabling microand macro-examinations of pre-surgical, intraoperative surgical, and post-surgical radio-oncological options, as well as long-term QoL issues.

\section{QoL MANAGEMENT - PRE- AND POST-TREATMENT CONSIDERATIONS}

KRANIOPHARYNGEOM 2007, a prospective, European multinational trial (Müller et al., 2003c, 2006b; Müller and Sörensen, 2007; Müller, 2010, 2011), is currently evaluating craniopharyngioma patients' prognoses (QoL, event-free, and overall survival rates) following defined therapeutic strategies. A stratified randomization of two treatment arms is conducted with respect to timing of postoperative irradiation (immediate irradiation versus irradiation at the time of progression) for the subgroup of patients $\geq 5$ years-of-age at the time of incomplete resection (Figure 4 ). The schedule of prospective data collection and the set and definition of parameters in KRANIOPHARYNGEOM 2007 are based on a European consensus (Müller et al., 2006a,c). The trial is open for international recruitment (www.kraniopharyngeom.net). There are also other current prospective studies underway on national and multinational levels to adopt strategies tailored to risk factors for morbidity and QoL (Garré and Cama, 2007; Puget et al., 2007).

A recent report (Müller et al., 2011b) shows that especially tumor involvement and surgical lesions of posterior parts of hypothalamic structures predisposes to adverse late effects such as obesity and consecutively impaired quality of life (Figure 5). The primary craniopharyngioma sequelae affecting patients' quality of life are visual impairment (Choux et al., 1991), hypothalamic lesions causing neuropsychological deficits (emotional instability, rage attacks, abnormal sexual behavior, and deficits of memory and intellectual capacities; Fischer et al., 1990; Fisher et al., 1998; Riva et al., 1998; Müller et al., 2005a,b; Pierre-Kahn et al., 2005), and endocrine deficits (including diabetes insipidus, hormonal deficiencies causing growth and puberty disturbances, hyperphagia and hypothalamic obesity, and eating disorders, which are observed in $40-50 \%$ of craniopharyngioma patients (DeVile et al., 1996b,c; Müller et al., 2001, 2003b,d, 2004a; Srinivasan et al., 2004).

Most patients (85-95\%) suffer from multiple deficits of hypothalamic-pituitary function, ranging to complete pituitary insufficiency (DeVile et al., 1996a; Merchant et al., 2002a), and full restoration of preoperatively deficient hormonal function occurs 


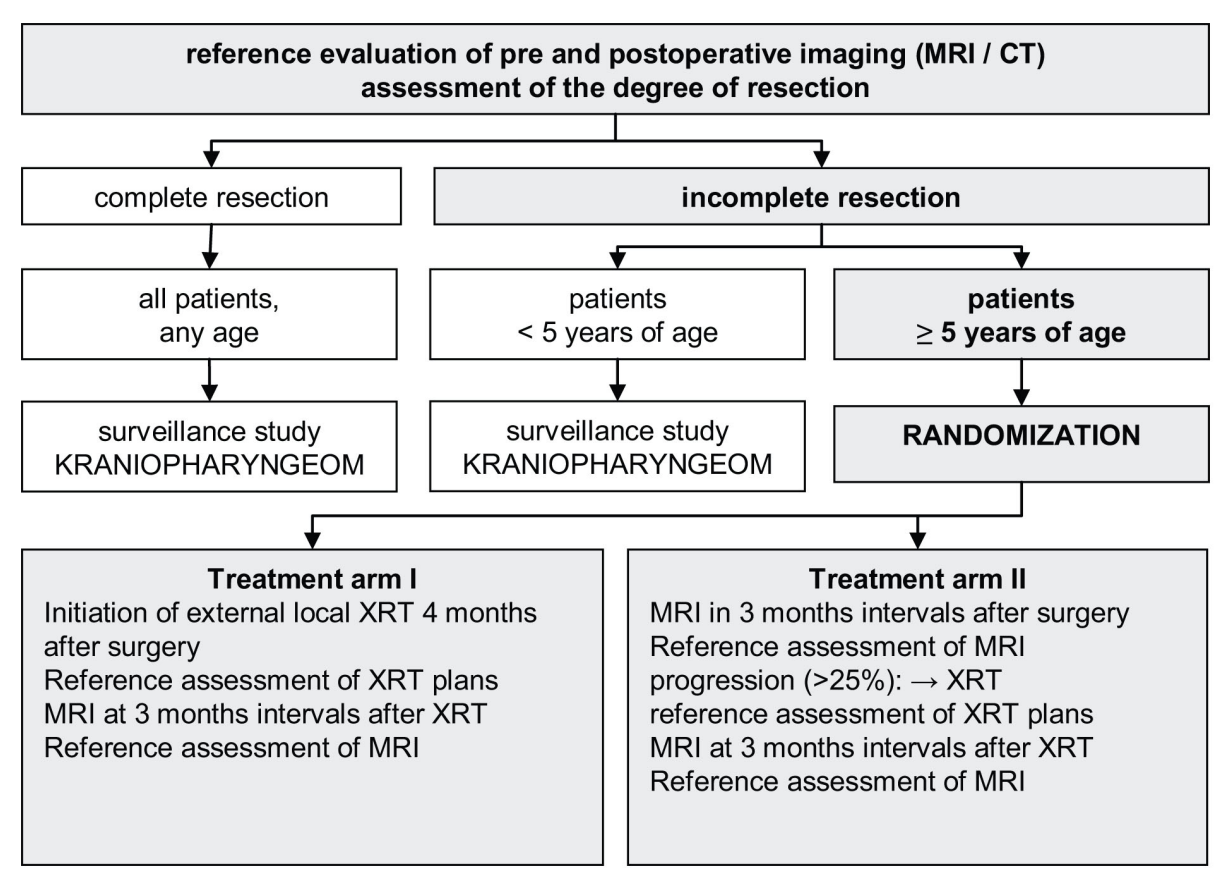

FIGURE 4 | Study design of KRANIOPHARYNGEOM 2007 (www.kraniopharyngeom.net; modified from Müller et al., 2006b, with the kind permission of Thieme).

only in rare cases (Honegger et al., 1999). Growth hormone substitution therapy is reported as a well-documented effective and safe treatment option in patients with growth hormone deficiency (Lustig et al., 2003b; Müller et al., 2010). Nevertheless, the disturbance of hypothalamic structures by the tumor and/or its treatment is considered to be the major pathogenic factor for hyperphagia and obesity, confirmed by an imaging study assessment of the extent of hypothalamic involvement and consequential sequelae (DeVile et al., 1996b). Another study performed by Roth et al. (1998) measured serum leptin levels in craniopharyngioma patients and found significantly elevated leptin concentrations in relation to BMI in patients with a suprasellar tumor components, finding that the body mass index (BMI) of affected patients positively correlated with the degree of hypothalamic damage. Normal inhibition of appetite after eating fails to occur because of disruption of the negative feedback loop involving leptin, formed in adipocytes, which binds to hypothalamic leptin receptors. Weight gain occurs in craniopharyngioma patients, even when caloric intake is similar in craniopharyngioma patients compared to BMI-matched controls (Harz et al., 2003).

Exacerbating the management of weight gain caused by craniopharyngioma and its treatment is that children with craniopharyngioma have a markedly lower than normal level of physical activity caused by daytime and disturbances of circadian rhythms (Müller et al., 2002). Initial trials with melatonin substitution in childhood craniopharyngioma patients have proved promising (Müller et al., 2006c). Polysomnographic studies in craniopharyngioma patients with severe daytime sleepiness reveal sleeping patterns typical for secondary narcolepsy (Müller et al., 2006d), confirming this sequela to be a major contributor to depreciated QoL. Mason et al. (2002) reported a significant weight loss in childhood craniopharyngioma patients treated with a central stimulating agent (dextroamphetamine).

Both the cause and treatment of weight gain in craniopharyngioma patients has been approached on several fronts. Lustig et al. (2003a,b) postulated hypothalamic disinhibition of vagal output as a cause of increased beta-cell stimulation, leading to hyperinsulinism and obesity. In a randomized, double-blinded study, treatment with a somatostatin analog (octreotide) to suppress beta-cell activity resulted in weight reduction. Due to reduced concentrations of catecholamine metabolites in the urine of patients with childhood craniopharyngioma correlating with the degree of obesity and the level of physical activity, Roth et al. (2007) hypothesized that craniopharyngioma patients' decreased physical activity and severe obesity might be related to decreased central sympathetic output. In another study, Roth et al. (2011) analyzed the gastrointestinal hormones ghrelin and peptide YY and their effect on satiety in patients with childhood craniopharyngioma and obesity, supporting that reduced ghrelin secretion coupled with reduced postprandial suppression of ghrelin leads to disturbed regulation of appetite in these patients. Peptide YY levels did not differ between normal weight, obese, and very obese patients with childhood craniopharyngioma. Recently reported (Roth et al., 2010) is a possible pathogenic role of peripheral alpha-melanocyte-stimulating hormone in childhood craniopharyngioma obesity. Even though initial experiences with bariatric surgery (laparoscopic adjustable gastric banding, LAGB) to treat severe craniopharyngioma obesity have been encouraging, long-term follow-up will be necessary to analyze its efficacy, safety, and long-term effect on weight development (Müller et al., 2007, 


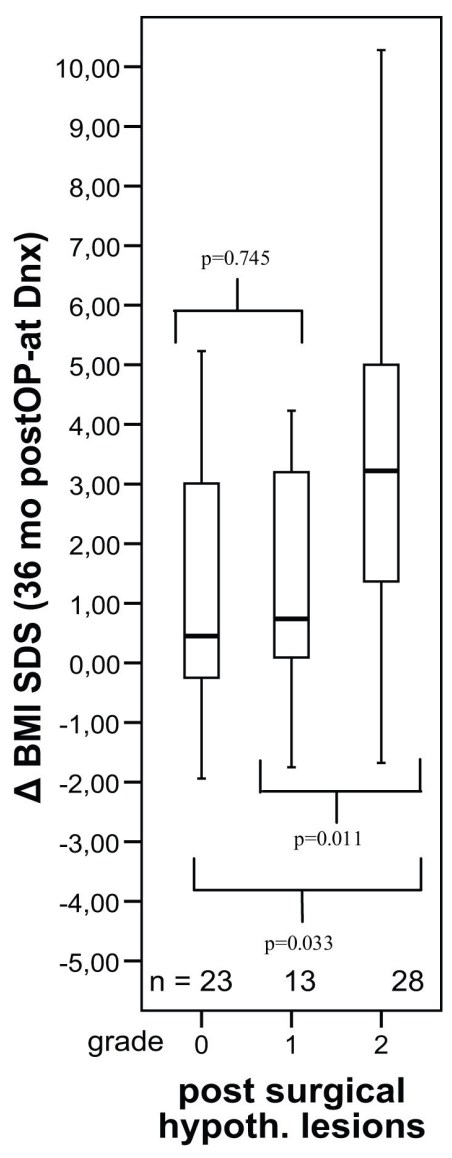

FIGURE 5 | Changes in body mass index (BMI SDS) during first 36 months after diagnosis of 117 childhood craniopharyngioma patients recruited in KRANIOPHARYNGEOM 2000 relative to the extent of surgical hypothalamic lesions (grade $\mathbf{0 - 2}$ ). The horizontal line in the middle of the box depicts the median. Edges of box mark the 25th and 75th percentile. Whiskers indicate the range of values that fall within 1.5 box-lengths. (Modified from Müller et al., 2011b, with the kind permission of BioScientifica).

2011a). As of this writing, there is no generally accepted pharmacological nor surgical therapy for craniopharyngioma obesity.

\section{CONCLUSION}

A retrospective study of functional capacity using the FMH instrument that quantifies patients' abilities to perform everyday psychomotor tasks (Wolff et al., 1996) found significantly lower rankings for craniopharyngioma patients compared to age-matched controls (Müller et al., 2003a, 2004b), with craniopharyngioma patients' morbid hypothalamic obesity cited as responsible for their low functional capacity self-rating. Age-dependent differences between childhood and adult onset craniopharyngioma are related to histological diagnosis, biological behavior, clinical manifestations, treatment options and follow-up (Koranyi et al., 2001; Attanasio et al., 2002; Kendall-Taylor et al., 2005). The KendallTaylor et al. (2005) study compared childhood craniopharyngioma with adult onset craniopharyngioma and reported a poor state of health and QoL in both cohorts. The majority of childhood and adult craniopharyngioma patients displayed pituitary insufficiency, with $60 \%$ suffering from diabetes insipidus. Nearly all patients were overweight or obese, reporting a poor QoL. What we can take away from this and other reports of both childhood and adult onset craniopharyngioma is that craniopharyngioma involves a series of chronic morbidities ranging from visual impairment to life-long, seemingly untreatable, unmanageable obesity that require on-going patient monitoring to optimize their QoL. Such monitoring provides a two-way communication platform that serves as both a data collection medium on how sequelae unfolds after treatment, as well as a patient-reporting medium of new treatment options that may be revealed as continuing research develops on this all-too confounding disease.

\section{ACKNOWLEDGMENTS}

Supported by the German Pediatric Cancer Foundation (Deutsche Kinderkrebsstiftung), Bonn (www.kinderkrebsstiftung.de). The author is grateful for the help of Mrs. Margarita Neff-Heinrich (Göttingen, Germany) in proofreading and editing of the manuscript.

DeVile, C. J., Grant, D. B., Hayward, R. D., and Stanhope, R. (1996a). Growth and endocrine sequelae of craniopharyngioma. Arch. Dis. Child. 75, 108-114.

DeVile, C. J., Grant, D. B., Hayward, R. D., Kendall, B. E., Neville, B. G. R., and Stanhope, R. (1996b). Obesity in childhood craniopharyngioma: relation to post-operative hypothalamic damage shown by magnetic resonance imaging. J. Clin. Endocrinol. Metab. 81, 2734-2737.

DeVile, C. J., Grant, D. B., Kendall, B. E., Neville, B. G. R., Stanhope, R., Watkins, K. E., and Hayward, R. D. (1996c). Management of childhood craniopharyngioma: can the morbidity of radical surgery be predicted? J. Neurosurg. 85, 73-81.
DiRocco, C., Caldarelli, M., Tamburrini, G., and Massimi, L. (2006). Surgical management of craniopharyngiomas - experience with a pediatric series. J. Pediatr. Endocrinol. Metab. 19(Suppl. 1), 355-366.

Einhaus, S. L., and Sanford, R. A. (2007). "Craniopharyngioma," in Principles and Practice of Pediatric Neurosurgery, eds A. L. Albright, I. F. Pollack, and P. D. Adelson (New York, NY: Thieme Medical Publishers), 545-562.

Fahlbusch, R., Honegger, J., Paulus, W., Huk, W., and Buchfelder, M. (1999). Surgical management of craniopharyngiomas: experience with 168 patients. J. Neurosurg. 90, 237-250. 
Fischer, E. G., Welch, K., Shillito, J., Winston, K. R., and Tarbell, N. J. (1990). Craniopharyngiomas in children. Long-term effects of conservative surgical procedures combined with radiation therapy. $\mathrm{J}$. $\mathrm{Neu}$ rosurg. $73,534-540$.

Fisher, P. G., Jenab, J., Goldthwaite, P. T., Tihan, T., Wharam, M. D., Foer, D. R., and Burger, P. C. (1998). Outcomes and failure patterns in childhood craniopharyngiomas. Childs Nerv. Syst. 14, 558-563.

Fitzek, M. M., Linggood, R. M., Adams, J., and Munzenrider, J. E. (2006). Combined proton and photon irradiation for craniopharyngioma: long-term results of the early cohort of patients treated at Harvard Cyclotron Laboratory and Massachusetts General Hospital. Int. J. Radiat. Oncol. Biol. Phys. 64, 1348-1354.

Garré, M. L., and Cama, A. (2007). Craniopharyngioma: modern concepts in pathogenesis and treatment. Curr. Opin. Pediatr. 19, 471-479.

Harz, K. J., Müller, H. L., Waldeck, E., Pudel, V., and Roth, C. (2003). Obesity in patients with craniopharyngioma: assessment of physical activity and food intake. J. Clin. Endocrinol. Metab. 88, 5227-5231.

Hetelekidis, S., Barnes, P. D., Tao, M. L., Fischer, E. G., Schneider, L., Scott, R. M., and Tarbell, N. J. (1993). 20year experience in childhood craniopharyngioma. Int. J. Radiat. Oncol. Biol. Phys. 27, 189-195.

Hölsken, A., Buchfelder, M., Fahlbusch, R., Blümcke, I., and Buslei, R. (2010). Tumour cell migration in adamantinomatous craniopharyngiomas is promoted by activated Wnt-signalling. Acta Neuropathol. 119, 631-639.

Honegger, J., Buchfelder, M., and Fahlbusch, R. (1999). Surgical resection of craniopharyngiomas: endocrinological results. $J$. Neurosurg. 90, 251-257.

Ierardi, D. F., Fernandes, M. J., Silva, I. R., Thomazini-Gouveia, J., Silva, N. S., Dastoli, P., Toledo, S. R., and Cavalheiro, S. (2007). Apoptosis in alpha interferon (IFN-alpha) intratumoral chemotherapy for cystic craniopharyngiomas. Childs Nerv. Syst. 23, 1041-1046.

Kendall-Taylor, P., Jönsson, P. J., Abs, R., Erfurth, E. M., KoltowskaHäggström, M., Price, D. A., and Verhelst, J. (2005). The clinical, metabolic and endocrine features and the quality of life in adults with childhood-onset craniopharyngioma compared with adult-onset craniopharyngioma. Eur. J. Endocrinol. 152, 557-567.

Koranyi, J., Svensson, J., Götherström, G., Sunnerhagen, K. S., Bengtsson, B., and Johannsson, G. (2001). Baseline characteristics and the effects of five years of $\mathrm{GH}$ replacement therapy in adults with GH deficiency of childhood or adulthood onset: a comparative, prospective study. J. Clin. Endocrinol. Metab. 86, 4693-4639.

Lustig, R. H., Hinds, P. S., RingwaldSmith, K., Christensen, R. K., Kasten, S. C., Schreiber, R. E., Rai, S. N., Lensing, S. Y., Wu, S., and Xiong, X. (2003a). Octreotide therapy of pediatric hypothalamic obesity: a doubleblind, placebocontrolled trial. J. Clin. Endocrinol. Metab. 88, 2586-2592.

Lustig, R. H., Post, S. R., Srivannaboon, K., Rose, S. R., Danish, R. K., Burghen, G. A., Xiong, X., Wu, S., and Merchant, T. E. (2003b). Risk factors for the development of obesity in children surviving brain tumours. J. Clin. Endocrinol. Metab. 88, 611-616.

Luu, Q. T., Loredo, L. N., Archambeau, J. O., Yonemoto, L. T., Slater, J. M., and Slater, J. D. (2006). Fractionated proton radiation treatment for pediatric craniopharyngioma: preliminary report. Cancer J. 12, 155-159.

Mason, P. W., Krawiecki, N., and Meacham, L. R. (2002). The use of dextroamphetamine to treat obesity and hyperphagia in children treated for craniopharyngioma. Arch. Pediatr. Adolesc. Med. 156, 887-892.

Merchant, T. E., Goloubeva, O., Pritchard, D. L., Gaber, M. W., Xiong, X., Danish, R. K., and Lustig, R. H. (2002a). Radiation dosevolume effects on growth hormone secretion. Int. J. Radiat. Oncol. Biol. Phys. 52, 1264-1270.

Merchant, T. E., Kiehna, E. N., Sanford, R. A., Mulhern, R. K., Thompson, S. J., Wilson, M. W., Lustig, R. H., and Kun, L. E. (2002b). Craniopharyngioma: the St. Jude Children's Research Hospital experience 1984-2001. Int. J. Radiat. Oncol. Biol. Phys. 53, 533-542.

Merchant, T. E., Kiehna, E. N., Kun, L. E., Mulhern, R. K., Li, C., Xiong, X., Boop, F. A., and Sanford, R. A. (2006). Phase II trial of conformal radiation therapy for pediatric patients with craniopharyngioma and correlation of surgical factors and radiation dosimetry with change in cognitive function. J. Neurosurg. 104, 94-102.

Moon, S. H., Kim, I. H., Park, S. W., Kim, I., Hong, S., Park, C. I., Wang, K. C., and Cho, B. K. (2005). Early adjuvant radiotherapy toward long-term survival and better quality of life for craniopharyngiomas - a study in single institute. Childs Nerv. Syst. 21 , 799-807.

Müller, H. L. (2006). More or less treatment strategies in childhood craniopharyngioma. Childs Nerv. Syst. 22, 156-157.

Müller, H. L. (2010). Childhood craniopharyngioma - current concepts in diagnosis, therapy and follow-up. Nat. Rev. Endocrinol. 6, 609-618.

Müller, H. L. (2011). Consequences after craniopharyngioma surgery in children. J. Clin. Endocrinol. Metab. 96, 1981-1991.

Müller, H. L., Albanese, A., Calaminus, G., Hargrave, D., Garré, M. L., Gebhardt, U., Saran, F., Sörensen, N., and Spoudeas, H. A. (2006a). Consensus and perspectives on treatment strategies in childhood craniopharyngioma - results of a meeting of the craniopharyngioma study group (SIOP), Genova 2004 J. Pediatr. Endocrinol. Metab. 19, 453-454.

Müller, H. L., Gebhardt, U., Pohl, F., Flentje, M., Emser, A., WarmuthMetz, M., Kolb, R., Calaminus, G. and Sörensen, N. (2006b). Relapse pattern after complete resection and early progressions after incomplete resection of childhood craniopharyngioma - update on KRANIOPHARYNGEOM 2000 and design of KRANIOPHARYNGEOM 2007. Klin. Padiatr. 218, 315-320.

Müller, H. L., Handwerker, G., Gebhardt, U., Faldum, A., Emser, A., Kolb, R., and Sörensen, N. $(2006 \mathrm{c})$. Melatonin treatment in obese patients with childhood craniopharyngioma and increased daytime sleepiness. Cancer Causes Control 17, 583-589.

Müller, H. L., Müller-Stöver, S., Gebhardt, U., Kolb, R., Sörensen, N. and Handwerker, G. (2006d). Secondary narcolepsy may be an underrated cause of increased daytime sleepiness in obese patients after childhood craniopharyngioma. J. Pediatr. Endocrinol. Metab. 19, 423-429.

Müller, H. L., Bruhnken, G., Emser, A. Faldum, A., Etavard-Gorris, N., Gebhardt, U., Kolb, R., and Sörensen, N. (2005a). Longitudinal study on quality of life in 102 survivors of childhood craniopharyngioma. Childs Nerv. Syst. 21, 975-980.

Müller, H. L., Gebhardt, U., Faldum, A., Emser, A., Etavard-Gorris, N., Kolb, R., and Sörensen, N. (2005b). Functional capacity and body mass index in patients with sellar masses - crosssectional study on 403 patients diagnosed during childhood and adolescence. Childs Nerv. Syst. 21, 539-545.

Müller, H. L., Bueb, K., Bartels, U., Roth, C., Harz, K., Graf, N., Korinthenberg, R., Bettendorf, M., Kühl, J., Gutjahr, P., Sörensen, N., and Calaminus, G. (2001). Obesity after childhood craniopharyngioma - German multicenter study on preoperative risk factors and quality of life. Klin. Padiatr. 213, 244-249.

Müller, H. L., Emser, A., Faldum, A., Bruhnken, G., Etavard-Goris, N., Gebhardt, U., Oeverink, R., Kolb, R., and Sörensen, N. (2004a). Longitudinal study on growth and body mass index before and after diagnosis of childhood craniopharyngioma. J. Clin. Endocrinol. Metab. 89, 3298-3305.

Müller, H. L., Gebhardt, U., EtavardGorris, N., Korenke, E., WarmuthMetz, M., Kolb, R., Sörensen, N., and Calaminus, G. (2004b). Prognosis and sequela in patients with childhood craniopharyngioma results of HIT-ENDO and update on KRANIOPHARYNGEOM 2000. Klin. Padiatr. 216, 343-348.

Müller, H. L., Faldum, A., EtavardGorris, N., Gebhardt, U., Oeverink, R., Kolb, R., and Sörensen, N. (2003a). Functional capacity, obesity and hypothalamic involvement crosssectional study on 212 patients with childhood craniopharyngioma. Klin. Padiatr. 215, 310-314.

Müller, H. L., Heinrich, M., Bueb, K. Etavard-Gorris, N., Gebhardt, U., Kolb, R., and Sörensen, N. (2003b). Perioperative dexamethasone treatment in childhood craniopharyngioma-influence on short-term and long-term weight development. $J$. Exp. Clin. Endocrinol. Diabetes 111, 330-334.

Müller, H. L., Kaatsch, P., WarmuthMetz, M., Flentje, M., and Sörensen, N. (2003c). Childhood craniopharyngioma - diagnostic and therapeutic strategies. Monatsschr. Kinderheilkd. 151, 1056-1063.

Müller, H. L., Schneider, P., EtavardGorris, N., Gebhardt, U., Kolb, R., and Sörensen, N. (2003d). Volumetric bone mineral density (BMD) in patients with childhood craniopharyngioma. Exp. Clin. Endocrinol. Diabetes 111, 168-173.

Müller, H. L., Gebhardt, U., Maroske, J., and Hanisch, E. (2011a). Longterm follow-up of morbidly obese patients with childhood craniopharyngioma after laparoscopic adjustable gastric banding (LAGB). Klin. Padiatr. 223, 372-373. 
Müller, H. L., Gebhardt, U., Teske, C., Faldum, A., Zwiener, I., WarmuthMetz, M., Pietsch, T., Pohl, F., Sörensen, N., and Calaminus, G. (2011b). Post-operative hypothalamic lesions and obesity in childhood craniopharyngioma: results of the multinational prospective trial KRANIOPHARYNGEOM 2000 after 3-year follow-up. Eur. J. Endocrinol. 165, 17-24.

Müller, H. L., Gebhardt, U., Schröder, S., Pohl, F., Kortmann, R.-D., Faldum, A., Zwiener, I., WarmuthMetz, M., Pietsch, T., Calaminus, G., Kolb, R., Wiegand, C., and Sörensen, N. (2010). Analyses of treatment variables for patients with childhood craniopharyngioma results of the multicenter prospective study trial KRANIOPHARYNGEOM 2000 after three years of follow up. Horm. Res. Paediatr. 73, 175-180.

Müller, H. L., Gebhardt, U., Wessel, V., Schröder, S., Kolb, R., Sörensen, N., Maroske, J., and Hanisch, E. (2007). First experiences with laparoscopic gastric banding (LAGB) in the treatment of obese patients with childhood craniopharyngioma. Klin. Padiatr. 219, 323-325.

Müller, H. L., Handwerker, G., Wollny, B., Faldum, A., and Sörensen, N. (2002). Melatonin secretion and increased sleepiness in childhood craniopharyngioma. J. Clin. Endocrinol. Metab. 87, 3993-3996.

Müller, H. L., and Sörensen, N. (2007). KRANIOPHARYNGEOM 2007 - Prospektive, multizentrische, Untersuchung von Kindern und Jugendlichen mit Kraniopharyngeom. Universitätsverlag Aschenbeck \& Isensee, Oldenburg.

Müller-Scholden, J., Lehrnbecher, T., Müller, H. L., Bensch, J., Hengen, R. H., Sörensen, N., and von Stockhausen, H. B. (2001). Radical surgery in a neonate with craniopharyngioma. Pediatr. Neurosurg. $33,265-269$.

Nielsen, E. H., Feldt-Rasmussen, U., Poulsgaard, L., Kristensen, L. O.,
Astrup, J., Jørgensen, J. O., Bjerre, P., Andersen, M., Andersen, C. Jørgensen, J., Lindholm, J., and Laurberg, P. (2011). Incidence of craniopharyngioma in Denmark $(\mathrm{n}=189)$ and estimated world incidence of craniopharyngioma in children and adults. J. Neurooncol. 104, 755-763.

Pierre-Kahn, A., Recassens, C., Pinto, G., Thalassinos, C., Chokron, S., Soubervielle, J. C., Brauner, R., Zerah, M., and Sainte-Rose, C. (2005). Social and psycho-intellectual outcome following radical removal of craniopharyngiomas in childhood. A prospective series. Childs Nerv. Syst. 21, 817-824.

Puget, S., Garnett, M., Wray, A., Grill, J., Habrand, J. L., Bodaert, N., Zerah, M., Bezerra, M., Renier, D., Pierre-Kahn, A., and Sainte-Rose, C. (2007). Pediatric craniopharyngiomas: classification and treatment according to the degree of hypothalamic involvement. J. Neurosurg. 106, 3-12.

Puget, S., Grill, J., Habrand, J. L., and Sainte-Rose, C. (2006). Multimodal treatment of craniopharyngioma: defining a risk-adapted strategy. J. Pediatr. Endocrinol. Metab. 19(Suppl. 1), 367-370.

Rajan, B., Ashley, S., Gorman, C., Jose, C. C., Horwich, A., Bloom, H. J. G., Marsh, H., and Brada, M. (1993). Craniopharyngioma long-term results following limited surgery and radiotherapy. Radiother. Oncol. 26, 1-10.

Regine, W. F., and Kramer, S. (1992). Pediatric craniopharyngiomas: long term results of combined treatment with surgery and radiation. Int. J. Radiat. Oncol. Biol. Phys. 24, 611-617.

Riva, D., Pantaleoni, C., Devoti, M., Saletti, V., Nichelli, F., and Giorgi, C. (1998). Late neuropsychological and behavioural outcome of children surgically treated for craniopharyngeoma. Childs Nerv. Syst. 14, 179-184.

Roth, C., Gebhardt, U., and Müller, H. L. (2011). Appetite-regulating hormone changes in patients with craniopharyngioma. Obesity (Silver Spring) 19, 36-41.

Roth, C., Hunneman, D., Gebhardt, U., Stoffel-Wagner, B., Reinehr, T. and Müller, H. L. (2007). Reduced sympathetic metabolites in urine of obese patients with craniopharyngioma. Pediatr. Res. 61, 496-501.

Roth, C., Wilken, B., Hanefeld, F., Schröter, W., and Leonhardt, U. (1998). Hyperphagia in children with craniopharyngioma is associated with hyperleptinemia and a failure in the down regulation of appetite. Eur. J. Endocrinol. 138, 89-91.

Roth, C. L., Enriori, P. J., Gebhardt, U., Hinney, A., Müller, H. L., Hebebrand, J., Reinehr, T., and Cowley, M. A. (2010). Changes of peripheral alpha-melanocyte-stimulating hormone in childhood obesity. Metab Clin. Exp. 59, 186-194.

Rushing, E. J., Giangaspero, F., Paulus, W., and Burger, P. C. (2007). "Craniopharyngioma," in WHO Classification of Tumours of the Central Nervous System, eds D. N. Louis, H. Ohgaki, O. D. Wiestler, and W. K. Cavanee (Lyon: IARC Press), 238-240.

Sanford, R. A. (1994). Craniopharyngioma: results of survey of the American Society of Pediatric Neurosurgery. Pediatr. Neurosurg. 21(Suppl. 1), 39-43.

Sherlock, M., Ayuk, J., Tomlinson, J. W., Toogood, A. A., Aragon-Alonso, A., Sheppard, M. C., Bates, A. S. and Stewart, P. M. (2010). Mortality in patients with pituitary disease. Endocr. Rev. 31, 301-342.

Srinivasan, S., Ogle, G. D., Garnett, S. P., Briody, I. N., Lee, J. W., and Cowell, C. T. (2004). Features of the metabolic syndrome after childhood craniopharyngioma. J. Clin. Endocrinol. Metab. 89, 81-86.

Stripp, D. C., Maity, A., Janss, A. J., Belasco, J. B., Tochner, Z. A., Goldwein, J. W., Moshang, T., Rorke, L. B., Phillips, P. C., Sutton, L. N., and Shu, H. K. (2004). Surgery with or without radiation therapy in the management of craniopharyngiomas in children and young adults. Int. J. Radiat. Oncol. Biol. Phys. 58, 714-720.

Tomita, T., and Bowman, R. M. (2005). Craniopharyngiomas in children: surgical experience at Children's Memorial Hospital. Childs Nerv. Syst. 21, 729-746.

Warmuth-Metz, M., Gnekow, A., Müller, H. L., and Sörensen, N. (2004). Differential diagnosis of suprasellar tumors in children. Klin. Padiatr. 216, 323-330.

Wolff, J. E., Daumling, E., Dirksen, A., Dabrock, A., Hartmann, M., and Jürgens, H. (1996). Münster Heidelberg abilities scale - a measuring instrument for global comparison of illness sequelae. Klin. Padiatr. 208, 294-298.

Yasargil, M. G., Curcic, M., Kis, M. Siegenthaler, G., Teddy, P. J., and Roth, P. (1990). Total removal of craniopharyngiomas. Approaches and long-term results in 144 patients. J. Neurosurg. 73, 3-11.

Conflict of Interest Statement: The author declares that the research was conducted in the absence of any commercial or financial relationships that could be construed as a potential conflict of interest.

Received: 28 July 2011; paper pending published: 16 August 2011; accepted: 21 October 2011; published online: 23 November 2011.

Citation: Müller HL (2011) Diagnostics, treatment, and follow-up in craniopharyngioma. Front. Endocrin. 2:70. doi: 10.3389/fendo.2011.00070

This article was submitted to Frontiers in Pituitary Endocrinology, a specialty of Frontiers in Endocrinology.

Copyright () 2011 Müller. This is an open-access article subject to a nonexclusive license between the authors and Frontiers Media SA, which permits use, distribution and reproduction in other forums, provided the original authors and source are credited and other Frontiers conditions are complied with. 